\title{
WILL CREATING NEW REGIONS IMPROVE THE REGIONAL WELFARE EQUALITY?
}

\author{
Aloysius Gunadi Brata
}

\begin{abstract}
This paper presents a preliminary effort to analyze the relationship between the region creation (pemekaran) and the regional inequality. Using the variation in the Human Development Index (HDI) that has been widely accepted as a measure of human development, this paper confirmed that pemekaran or creation of new regions have caused regional inequality becoming more severe.

A 'damaging power' of pemekaran has also reduced the benefit of decentralization to improve regional equality. Since the analysis shows that pemekaran is not a solution for regional inequality, therefore the policy implication of this finding is that pemekaran should be controlled. A reverse process of pemekaran is amalgamation or consolidation of regions. However this policy is rather difficult to be implemented because it is mainly related to resistance of local elites and furthermore there is no guarantee that the amalgamation will improve quality of public services. Perhaps moratorium of pemekaran as a moderate choice could be an acceptable policy.
\end{abstract}

JEL Classification: H75, R11, R58

Keywords: region creation, human development index, inequality.

\footnotetext{
1 Earlier version of the paper was presented at the Indonesian Regional Science Association Ninth International Conference: "The Current and Future Issues of Regional Development, Energy and Climate Change", Palembang, July 31 - August 1, 2008.

2 Faculty of Economics, Univeristy of Atma Jaya Yogyakarta, aloy.gb@gmail.com, aloy.gb@fe.uajy.ac.id
} 


\section{INTRODUCTION}

Pemekaran or the creation of new regions is a controversial phenomenon in the recent development of decentralization in Indonesia. The number of sub-national administration in this country has increased significantly in the recent years. There were only 341 municipalities (kota) and districts (kabupaten) in 1999. However, as shown in Table IV.1, the number of the regions in 2007 has increased up to more than 450. Most of new regions were created outside Java. This process has spurred territorial changes in this archipelagic country that regional inequality is a critical issue until the present days (Garcia and Soelistianingsih 1998, Tadjoeddin et al. 2001, Suryadarma et al. 2006). Moreover, in the Indonesia Human Development Report 2004, the process of decentralization has also been expected to raise the prospect of increased regional inequality (BPS-BAPPENAS-UNDP 2004, see also Hill and Shiraisi 2007).

Fitrani et al. (2005) found that several factors influence the likelihood of creating new regions. These factors are geographic dispersion, political and ethnic diversity, natural resources wealth and scope for bureaucratic rent seeking. Meanwhile, according to Nordhold and Klinken (2007) the creation of new regions in the recent years of decentralization is a local driven process. In this process, the local elites played an important role. There are several motivations for the local elites to propose a division of a region. One of important motivations is to satisfy their own interests, such as political and economic interests. However, most of elites said that the main purpose of pemekaran is to improve the welfare of citizens in the new region. This reason was also accompanied by an argument that pemekaran may reflect a local response to the inequality that has been described as an 'aspiration to inequality' (Tadjoeddin'et al. 2001). Therefore,'pemekaran was also claimed to be able to reduce the disparity between new and original regions (daerah induk).

\begin{tabular}{|c|c|c|c|c|c|}
\hline \multirow{3}{*}{ Island } & \multicolumn{4}{|c|}{$\begin{array}{l}\text { Table IV.1 } \\
\text { Is by Major Islands, 1996-2007 }\end{array}$} & \\
\hline & \multicolumn{5}{|c|}{ Number of Regions } \\
\hline & 1996 & 1999 & 2002 & 2005 & $2007 *$ \\
\hline Sumatra & 74 & 96 & 110 & 132 & 136 \\
\hline Java/Bali & 116 & 119 & 124 & 124 & 125 \\
\hline Nusa Tenggara & 20 & 21 & 23 & 25 & 28 \\
\hline Kalimantan & 29 & 38 & 48 & 52 & 53 \\
\hline Sulawesi & 40 & 45 & 50 & 62 & 69 \\
\hline Maluku/Papua & 18 & 22 & 36 & 45 & 45 \\
\hline Indonesia & 297 & 341 & 391 & 440 & 456 \\
\hline
\end{tabular}


However, indicative evidence shows negative impacts on this territorial reform. A report on decentralization in Indonesia produced by USAID-DRSP (2006) pointed out some negative consequences of pemekaran. First, inefficient administration as per capita costs of government increased sharply. Second, decreased capacity to adequately discharge the function assigned uniformly to all districts/cities. Third, pemekaran increased the potential of inter-group conflict. All of these negative consequences may hinder a reduction of the regional inequality. In other words, there is a controversy on the impact of pemekaran on the regional inequality. Moreover, this report also mentioned that the impacts of pemekaran have not been well studied.

The aim of this paper is to describe the relation between pemekaran and regional inequality. Variation in income or Gross Regional Domestic Product (GRDP) was widely used as a measure of regional inequality in Indonesia (i.e. Garcia and Soelistianingsih 1998, Akita and Alisjahbana 2002, Resosudarmo and Vidyattama 2006). However, this paper uses variation in the Human Development Index (HDI) that has been widely accepted as a measure of human development. The HDI measures the overall achievements in a country or region in three basic dimensions of human development: longevity (measured by life expectancy), knowledge (measured by education attainment), and a decent standard of living (measured by adjusted income) (BPSBAPPENAS-UNDP 2004). In his study on local planning and human development in Indonesia, Heikkila (1999) used HDI. Tadjoeddin et al. (2001) also employed elements of HDI as the social welfare indicators to explain regional unrest in Indonesia. Meanwhile, Haddad and NedoviBudi (2006) used the HDI in their study on the intra-urban inequality among the districts of São Paulo municipality. A recent study organized by the United Nations also focused on the spatial disparities in human development in Asia (Kanbur et al. 2006).

\section{REGIONAL VARIATION IN HUMAN DEVELOPMENT: AN OVERVIEW}

As already mentioned in the previous section, the HDI consists of three basic dimensions of human development. Figure IV. 1 shows the coefficient variations of these components among provinces from 1996 to 2005. Among four components, the mean years of schooling (MYS) was the component with highest variation, while component with the lowest variation was the adjusted per capita real expenditure (RE). Meanwhile, the regional variation of life expectancy (LE) and literacy rate (LR) were in between the variation of MYS and RE. It indicates that the regional inequality in human development in Indonesia have been intensively related to the inequality in the longevity and knowledge components. The figure also shows that regional inequality of $\mathrm{HDI}$ in Indonesia has decreased quite slowly in the entire periods. 


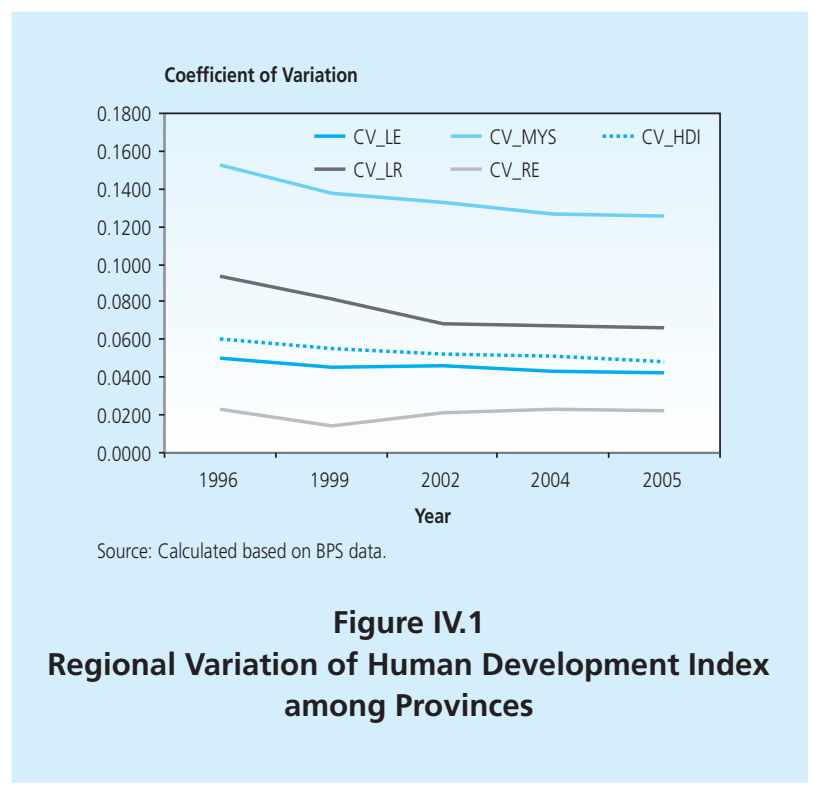

Compared to other Asian countries, the regional inequality in the HDI in Indonesia was smaller than China but larger than Malaysia (Table IV.2). In 2003, the coefficient of variation of $\mathrm{HDI}$ in Malaysia and China were 0.050 and 0.088 respectively. Meanwhile, this variation in Indonesia in 2002 was 0.053 and decreased to 0.051 in 2004. According to Kanbur et al. (2006), there was a rise in inequality in some Asian countries that possibly related to the economic reforms.

\begin{tabular}{|c|c|c|c|}
\hline \multicolumn{4}{|c|}{$\begin{array}{c}\text { Table IV.2 } \\
\text { Regional Variation of Human Development Index Amor } \\
\text { Malaysia and China }\end{array}$} \\
\hline Country & Year & $\begin{array}{c}\text { Number of Provinces } \\
\text { or States }\end{array}$ & $\begin{array}{l}\text { Coefficient of } \\
\text { Variation of HDI }\end{array}$ \\
\hline Indonesia & 2002 & 30 & 0.053 \\
\hline Indonesia & 2004 & 33 & 0.051 \\
\hline Malaysia & 2003 & 14 & 0.050 \\
\hline China & 2003 & 31 & 0.088 \\
\hline
\end{tabular}

Indonesia has also adopted many reforms after it was hit by the economic crisis. One of the important reforms in Indonesia was decentralization that has also opened opportunities for a pemekaran of a region. Although Figure IV.1 shows that regional inequality in HDI among provinces in Indonesia was fairly stable, there is a question on the inequality within provinces. 
This question is related to pemekaran that has changed the territorial structure of this country. BPS-BAPPENAS-UNDP (2004) have mentioned that pemekaran of some districts caused a dramatic rises and falls of the HDI in the divided regions. This report pointed out that the better parts of the splitting districts register an increase in HDI while the worse experience a decrease.

As shown in Table IV.3, Bangka Selatan and Pegunungan Bintang are registered as the lowest rank in $\mathrm{HDI}$, while Kota Sorong is registered as the highest rank in respective islands. These three regions were known as new districts. In other words, this table indicates that creating new regions may increase the inequality of HDI. In international standard, there are three clusters of achievement in human development, i.e. high human development (with an HDI of 0.800 or above), medium human development (HDI of 0.500-0.799) and low human development (HDI of less than 0.500). Based on this standard, in 2005 there were seven districts in the low cluster in HDI. These districts are in the Papua Island and most of them were registered as new districts. These districts are Pegunungan Bintang, Mappi, Asmat, Yahukimo, Boven Digoel and Talikora. It should also be mentioned that almost all districts in the lowest group in HDI since 1996 to 2005 are located in the Eastern Indonesia.

In order to analyze impact of pemekaran on the inequality within provinces, this paper uses coefficient of variation of HDI as an indicator. Table IV.4 shows this indicator that is calculated

\begin{tabular}{|c|c|c|c|c|}
\hline \multicolumn{5}{|c|}{$\begin{array}{l}\text { Table IV.3 } \\
\text { Highest Ra }\end{array}$} \\
\hline \multirow{2}{*}{ Island } & \multicolumn{4}{|c|}{ Lowest } \\
\hline & 1996 & 1999 & 2002 & 2005 \\
\hline $\begin{array}{l}\text { Sumatra } \\
\text { Java/Bali } \\
\text { Kalimantan } \\
\text { Nusa Tenggara } \\
\text { Sulawesi } \\
\text { Maluku/Papua } \\
\text { INDONESIA }\end{array}$ & $\begin{array}{l}\text { Nias (55.5) } \\
\text { Sampang (48.2) } \\
\text { Sambas (57.4) } \\
\text { Lombok Tengah (51.2) } \\
\text { Jeneponto (58.1) } \\
\text { Maluku Tengah (64.6) } \\
\text { Jaya Wijaya (43.9) }\end{array}$ & $\begin{array}{l}\text { Nias (50.4) } \\
\text { Sampang (47.3) } \\
\text { Sambas (55.8) } \\
\text { Sumba Barat (45.4) } \\
\text { Jeneponto (56.9) } \\
\text { Paniai (43.6) } \\
\text { Paniai (43.6) }\end{array}$ & $\begin{array}{l}\text { Sawah Lunto/Sijunjung (61.5) } \\
\text { Sampang (49.7) } \\
\text { Sambas (59.3) } \\
\text { Sumba Barat (53.4) } \\
\text { Jeneponto (57.8) } \\
\text { Jaya Wijaya (47) } \\
\text { Jaya Wijaya (47) }\end{array}$ & $\begin{array}{l}\text { Bangka Selatan (63.0) } \\
\text { Sampang (55.0) } \\
\text { Sambas (61.9) } \\
\text { Lombok Barat (57.8) } \\
\text { Jeneponto (60.9) } \\
\text { Pegunungan Bintang (46.9) } \\
\text { Pegunungan Bintang (46.9) }\end{array}$ \\
\hline \multirow{2}{*}{ Island } & \multicolumn{4}{|c|}{ Highest } \\
\hline & 1996 & 1999 & 2002 & 2005 \\
\hline $\begin{array}{l}\text { Sumatra } \\
\text { Java/Bali } \\
\text { Kalimantan } \\
\text { Nusa Tenggara } \\
\text { Sulawesi } \\
\text { Maluku/Papua } \\
\text { INDONESIA }\end{array}$ & $\begin{array}{l}\text { Kota Bukit Tinggi (76.1) } \\
\text { Kota Jakarta Selatan (77.2) } \\
\text { Kota Palangka Raya (76.9) } \\
\text { Kota Mataram (64.6) } \\
\text { Kota Manado (76.2) } \\
\text { Kota Ambon (74.3) } \\
\text { Kota Jakarta Selatan (77.2) }\end{array}$ & $\begin{array}{l}\text { Kota Bengkulu (71.8) } \\
\text { Kota Jakarta Selatan (75.1) } \\
\text { Kota Palangka Raya (72.3) } \\
\text { Kota Kupang (66.6) } \\
\text { Kota Manado (72.5) } \\
\text { Kota Ambon (73.0) } \\
\text { Kota Jakarta Selatan (75.1) }\end{array}$ & $\begin{array}{l}\text { Kota Pematang Siantar }(74.1) \\
\text { Kota Jakarta Timur }(76.0) \\
\text { Kota Palangka Raya }(74.2) \\
\text { Kota Kupang }(70.9) \\
\text { Kota Manado }(74.2) \\
\text { Kota Sorong }(73.0) \\
\text { Kota Jakarta Timur }(76.0)\end{array}$ & $\begin{array}{l}\text { Kota Batam (76.5) } \\
\text { Kota Jakarta Selatan (77.9) } \\
\text { Kota Palangka Raya (77.0) } \\
\text { Kota Kupang (74.5) } \\
\text { Kota Makasar (76.6) } \\
\text { Kota Ambon (76.2) } \\
\text { Kota Jakarta Selatan (77.9) }\end{array}$ \\
\hline
\end{tabular}


based on the available data published by BPS. In 1996, the lowest inequality in HDI was Jakarta, while the highest was Papua. Compared to other provinces, inequality in Papua was very extreme. The coefficient of variation of $\mathrm{HDI}$ in Papua was almost twice the coefficient of variation in Indonesia. There were three provinces in 1996 in which their inequality is larger than the variation level in Indonesia. These provinces were West Nusa Tenggara, East Java and of course Papua. This table also confirmed that inequality in the Eastern Indonesia was higher than other parts of Indonesia.

A similar picture was found in 1999. Inequality in West Nusa Tenggara, East Java and Papua were still registered larger than inequality in Indonesia. Meanwhile, a significant increase of coefficient of variation in East Nusa Tenggara caused this province to become the second highest inequality among provinces. An increase in the average of inequality in Eastern Indonesia has caused an increase in the gap of equality between Eastern and Western Indonesia. There were nine provinces that experienced an increase in inequality. These provinces are spread across the islands. However, Sumatra contributed four provinces in this group. At national level, coefficient of variation of $\mathrm{HDI}$ increased to 0.0783 in 1999. As a note, the trend of inequality based on district data is the opposite to the trend of inequality among provinces (Figure IV.1).

In 2002 there were only two provinces that their inequalities are higher than the national average. These provinces are Papua and East Java. From 1996 to 2002, both provinces always experienced higher inequality in HDI. High inequality in East Java could be explained by the fact that HDI in districts in Madura were lower than other districts in this province. The table also shows that compared to 1999, the gap of inequality between Eastern and Western Indonesia has decreased. Other interesting finding is although the inequality at Indonesia level in 2002 has decreased, unfortunately there was an increase in the number of provinces that experienced an increase in inequality. More than a half of member of this group were provinces that experienced pemekaran, such as West Java, Aceh and Maluku. In 2000, West Java was divided into two provinces with Banten as the new province. Meanwhile, there were seven new districts in Aceh that were created in 2001-2002. Maluku also registered a split into Maluku and North Maluku. However, Papua and Central Kalimantan show different pattern this year. Both provinces experienced pemekaran significantly; however, there was no increase in the inequality in HDI. These findings indicate that pemekaran may result in mixed impacts on the inequality within provinces.

The highest variation in HDI in 2005 was found in Papua. Since 1996 until 2005, this province remained at the lowest rank in the equality in Indonesia. Moreover, inequality in Papua in 2005 became more serious compared to situation in 1996. The coefficient of variation of 


\begin{tabular}{|c|c|c|c|c|c|c|c|}
\hline \multicolumn{8}{|c|}{$\begin{array}{c}\text { Table IV.4 } \\
\text { Regional Variation of Human Development Index within Provinces }\end{array}$} \\
\hline \multirow[t]{2}{*}{ Island } & \multicolumn{4}{|c|}{ Coefficient of Variation } & \multicolumn{3}{|c|}{$\begin{array}{c}\text { Change of Coefficient of } \\
\text { Variation }\end{array}$} \\
\hline & 1996 & 1999 & 2002 & 2005 & 1999 & 2002 & 2005 \\
\hline Nanggroe Aceh Darusslam & 0.0371 & 0.0366 & 0.0444 & 0.0383 & -0.0005 & 0.0079 & -0.0061 \\
\hline North Sumatra & 0.0655 & 0.0735 & 0.0448 & 0.0390 & 0.0079 & -0.0287 & -0.0058 \\
\hline West Sumatra & 0.0566 & 0.0495 & 0.0562 & 0.0507 & -0.0071 & 0.0067 & -0.0056 \\
\hline Riau & 0.0403 & 0.0442 & 0.0358 & 0.0323 & 0.0038 & -0.0083 & -0.0035 \\
\hline Jambi & 0.0383 & 0.0362 & 0.0318 & 0.0217 & -0.0022 & -0.0044 & -0.0101 \\
\hline South Sumatra & 0.0521 & 0.0682 & 0.0460 & 0.0345 & 0.0161 & -0.0222 & -0.0115 \\
\hline Bengkulu & 0.0700 & 0.0710 & 0.0615 & 0.0558 & 0.0010 & -0.0095 & -0.0057 \\
\hline Lampung & 0.0502 & 0.0449 & 0.0488 & 0.0406 & -0.0053 & 0.0039 & -0.0081 \\
\hline Kep. Bangka Belitung & N/A & N/A & 0.0362 & 0.0484 & N/A & N/A & 0.0122 \\
\hline Kep. Riau & N/A & N/A & $\mathrm{N} / \mathrm{A}$ & 0.0399 & N/A & N/A & N/A \\
\hline DKI Jakarta & 0.0124 & 0.0211 & 0.0067 & 0.0513 & 0.0087 & -0.0143 & 0.0446 \\
\hline West Java & 0.0552 & 0.0517 & 0.0559 & 0.0467 & -0.0034 & 0.0042 & -0.0092 \\
\hline Central Java & 0.0445 & 0.0415 & 0.0443 & 0.0375 & -0.0030 & 0.0028 & -0.0068 \\
\hline DI Yogyakarta & 0.0570 & 0.0566 & 0.0475 & 0.0462 & -0.0004 & -0.0091 & -0.0013 \\
\hline East Java & 0.0908 & 0.0889 & 0.0879 & 0.0754 & -0.0018 & -0.0011 & -0.0124 \\
\hline Banten & $N / A$ & N/A & 0.0659 & 0.0527 & $N / A$ & N/A & -0.0132 \\
\hline Bali & 0.0608 & 0.0640 & 0.0666 & 0.0473 & 0.0032 & 0.0026 & -0.0193 \\
\hline West Kalimantan & 0.0563 & 0.0427 & 0.0359 & 0.0312 & -0.0136 & -0.0069 & -0.0047 \\
\hline Central Kalimantan & 0.0417 & 0.0367 & 0.0340 & 0.0259 & -0.0050 & -0.0027 & -0.0082 \\
\hline South Kalimantan & 0.0376 & 0.0347 & 0.0475 & 0.0355 & -0.0028 & 0.0127 & -0.0120 \\
\hline East Kalimantan & 0.0258 & 0.0360 & 0.0430 & 0.0307 & 0.0102 & 0.0071 & -0.0124 \\
\hline West Nusa Tenggara & 0.0852 & 0.0838 & 0.0665 & 0.0586 & -0.0014 & -0.0173 & -0.0079 \\
\hline East Nusa Tenggara & 0.0454 & 0.1030 & 0.0699 & 0.0535 & 0.0575 & -0.0331 & -0.0164 \\
\hline North Sulawesi & 0.0448 & 0.0412 & 0.0293 & 0.0196 & -0.0036 & -0.0119 & -0.0097 \\
\hline Central Sulawesi & 0.0575 & 0.0539 & 0.0444 & 0.0376 & -0.0036 & -0.0095 & -0.0068 \\
\hline South Sulawesi & 0.0522 & 0.0516 & 0.0545 & 0.0509 & -0.0006 & 0.0029 & -0.0036 \\
\hline South East Sulawesi & 0.0363 & 0.0499 & 0.0542 & 0.0461 & 0.0136 & 0.0043 & -0.0082 \\
\hline Gorontalo & N/A & N/A & 0.0331 & 0.0390 & $\mathrm{~N} / \mathrm{A}$ & N/A & 0.0059 \\
\hline West Sulawesi & $N / A$ & N/A & $\mathrm{N} / \mathrm{A}$ & 0.0262 & $\mathrm{~N} / \mathrm{A}$ & $\mathrm{N} / \mathrm{A}$ & N/A \\
\hline Maluku & 0.0592 & 0.0491 & 0.0603 & 0.0521 & -0.0101 & 0.0112 & -0.0082 \\
\hline North Maluku & N/A & N/A & 0.0599 & 0.0461 & N/A & N/A & -0.0139 \\
\hline West Irian Jaya & $\mathrm{N} / \mathrm{A}$ & N/A & N/A & 0.0736 & N/A & N/A & N/A \\
\hline Papua & 0.1449 & 0.1394 & 0.1117 & 0.1542 & -0.0054 & -0.0277 & 0.0425 \\
\hline Western Indonesia & 0,0665 & 0,0655 & 0,0613 & 0,0519 & $-0,0011$ & $-0,0042$ & $-0,0094$ \\
\hline Eastern Indonesia & 0,0920 & 0,1007 & 0,0815 & 0,0898 & 0,0087 & $-0,0191$ & 0,0083 \\
\hline Indonesia & 0.0774 & 0.0783 & 0.0700 & 0.0698 & 0.0009 & -0.0083 & -0.0002 \\
\hline
\end{tabular}

HDI in Papua was more than twice the variation in Indonesia. This province was split into two provinces. Irian Jaya Barat, the new province in the Papua Island, also experienced a high inequality among the provinces. It indicates that the regional division of Papua province into Papua and West Irian Jaya has increased inequality in Papua as the original province. Besides 
both provinces, East Java also experienced a higher inequality than other provinces. In general, there was an increase in the inequality in the Eastern and a decrease in the Western Indonesia. Therefore, compared to the Western Indonesia, inequality in the Eastern became poorer. This year, there were four provinces experienced an increase of inequality within the province. Two of them are new provinces, Gorontalo in Sulawesi and Bangka Belitung in Sumatra. This finding gives other indication that there is a relation between pemekaran and the inequality within province.

Based on the above discussion, several conclusions could be drawn. First, inequality within the province in the Eastern Indonesia provinces was higher than other provinces. Second, pemekaran appeared to influence inequality within the province. Third, there was a slow decrease of inequality within the province that raised a question on the benefit of decentralization in reducing the inequality in $\mathrm{HDI}$ or the welfare of citizens.

\section{THE IMPACT OF PEMEKARAN ON THE INEQUALITY WITHIN THE PROVINCE: A PRELIMINARY ESTIMATION}

The previous section has mentioned that pemekaran might influence the inequality within the province. In this section, the impact of pemekaran is assessed by employing the number of regions in each province as an explanatory variable in the regression model. As commonly known, pemekaran increase the number of regions, therefore it is reasonable to assess the impact of pemekaran on the inequality within the province (Covar_HDI) through the number of regions variable (Num_reg).

Besides the estimate of the initial model (Model A), the analysis also includes other variable in the Model B and C (Table IV.5). Year dummy of decentralization (Decent_dummy) is introduced in the model to capture the overall changes related to decentralization policy that has been implemented since 2001. According to some authors, decentralization is not a panacea for addressing all human development issues (Scott 2006) and its impact on poverty and equity is rather mixed (Islam 2003). BPS-BAPPENAS-UNDP (2004) had also mentioned that decentralization

\begin{tabular}{|c|c|c|c|c|c|}
\hline \multicolumn{6}{|c|}{$\begin{array}{c}\text { Table IV.5 } \\
\text { Descriptive Statistics of the Main Variables }\end{array}$} \\
\hline & $\mathbf{N}$ & Minimum & Maximum & Mean & Std. Dev. \\
\hline Covar_HDI & 115 & .01 & .15 & .052 & .0231 \\
\hline Num_reg & 115 & 3.00 & 38.00 & 12.774 & 8.799 \\
\hline Gl & 108 & .22 & .42 & .297 & .039 \\
\hline
\end{tabular}


entails risks, particularly that of widening disparities as indicated by disparity in the local revenue between the rich endowment and the poor regions.

Other variable used in the model (C) is Gini Index (GI) at the provincial level. This variable is introduced to represent the impact of economic inequality on the HDI inequality. In the case of India, Majumber (2005) indicated that the economic reform may have excluded a substantial portion of population from economic processes. This exclusion caused an increase in the economic equality that reduced equality in the human development. Since economic reforms in Indonesia have been suspected to impoverish people, therefore coefficient of Gini Index might be expected to show a positive sign.

\begin{tabular}{|c|c|c|c|}
\hline & Regr & (OLS) & \\
\hline & (A) & (B) & (C) \\
\hline Constant & $\begin{array}{c}0.043 \\
(11.700)^{*}\end{array}$ & $\begin{array}{c}0.040 \\
(9.205)^{\star}\end{array}$ & $\begin{array}{l}0.005 \\
(0.314)\end{array}$ \\
\hline Num_reg & $\begin{array}{c}0.001 \\
(2.725)^{*}\end{array}$ & $\begin{array}{c}0.001 \\
(3.710)^{\star}\end{array}$ & $\begin{array}{c}0.001 \\
(3.007)^{*}\end{array}$ \\
\hline Eastin_dummy & & $\begin{array}{c}0.018 \\
(4.203)^{\star}\end{array}$ & $\begin{array}{c}0.015 \\
(3.467)^{*}\end{array}$ \\
\hline Decen_dummy & & $\begin{array}{c}-0.008 \\
(-2.151)^{\star *}\end{array}$ & $\begin{array}{c}-0.011 \\
(-2.801)^{*}\end{array}$ \\
\hline Gl & & & $\begin{array}{c}0.131 \\
(2.498)^{\star *}\end{array}$ \\
\hline Adj. R-squared & 0.053 & 0.192 & 0.213 \\
\hline Number of observation & 115 & 115 & 108 \\
\hline
\end{tabular}

Regarding availability of data, the number of observation in Model A and B are 115, while in model $C$ are 108. The provincial panel data set for 1996-2005 was constructed mainly from the Indonesia Human Development Report 2001 and 2004 published by BPS-BAPPENASUNDP, and from http://www/datastatistik-indonesia.com. Descriptive statistics of main variables are presented in Table IV.4. The ordinary least square (OLS) is used to estimate the equations.

In the result from Model A, the coefficient of Num_reg is significant at one percent level. In indicates that an increase in the number of regions in a province has caused an increase in the inequality within province. Since the increase in the number of regions is a result of pemekaran, then this finding confirmed the impact of pemekaran on an increase in the inequality. Meanwhile, in Model B, all of dummy variables are significant at least at five percent level. Positive sign of coefficient of Eastin_dummy indicates that there was a difference in the inequality 
between Eastern and Western Indonesia regions. It confirmed that inequality in the Eastern Indonesia was higher than the Western part of Indonesia. Negative sign of Decen_dummy indicates that the inequality within the province after decentralization (2002-2005) was lower than before decentralization. This finding supports a positive expectation on the impact of decentralization to reduce inequality among regions in a province. Unfortunately, this benefit appeared to have been reduced by pemekaran. In other words, pemekaran in the decentralization years have made inequality in human development became more complicated. In addition, coefficient of $G$ in Model C confirmed that high economic inequality has increased inequality in the human development. It means that reducing welfare inequality within province needs a comprehensive policy that is also designed to reduce the economic inequality.

As already mentioned, the focus of this paper is to assess the impact of pemekaran on the regional inequality. In general, the above findings show that there is what might be called a 'damaging power' of pemekaran on the regional inequality. Meanwhile, since the adjusted $R$ squared in all of the estimation results are quite small, these results also confirmed that there are other variables that might influence the inequality within the province.

\section{CONCLUSION}

This paper presented a preliminary analysis on the impact of pemekaran on the regional inequality that is represented by coefficient of variation in HDI. Regarding this analysis, the weaknesses of this paper should be mentioned. First, the use of the OLS in this analysis might reduce robustness of estimation. It implies that the use of panel data estimation perhaps would give a better result. Second, the empirical models used in this paper omitted other variables that theoretically affect inequality, such as the local government expenditure policy.

By considering the above weaknesses, this paper confirmed that pemekaran or creation of new regions have caused regional inequality becoming more severe. A 'damaging power' of pemekaran has also reduced the benefit of decentralization to improve regional equality. Since the analysis shows that pemekaran is not a solution for regional inequality, therefore the policy implication of this finding is that pemekaran should be controlled. A reverse process of pemekaran is amalgamation or consolidation of regions. However this policy is rather difficult to be implemented because it is mainly related to resistance of local elites, and there is no guarantee amalgamation will improve quality of public services (Brata 2007). Perhaps moratorium of pemekaran as a moderate choice could be an acceptable policy. 


\section{REFERENCES}

Akita, Takahiro dan Armida S. Alisjahbana (2002), 'Regional Income Inequality in Indonesia and the Initial Impact of the Economic Crisis', Bulletin of Indonesian Economic Studies 38(2): 201-22.

BPS-BAPPENAS-UNDP (2001), Indonesia Human Development Report 2001, BPS-BAPPENASUNDP, Jakarta.

BPS-BAPPENAS-UNDP (2004), Indonesia Human Development Report 2004, BPS-BAPPENASUNDP, Jakarta.

Brata, Aloysius G. (2007), 'Konsolidasi Daerah dan Pelayanan Publik', paper presented at Seminar Internasional Ke Delapan Dinamika Politik Lokal Di Indonesia: “Penataan Daerah (Territorial Reform) dan Dinamikanya", Yayasan Percik-Ford Foundation, Salatiga, July 17-19, 2007.

Fitrani, Fitria, Bert Hofman dan Kai Kaiser (2005). 'Unity in Diversity? The Creation of New Local Governments in a Decentralizing Indonesia', Bulletin of Indonesian Economic Studies 41 (1): 57-79.

Garcia, Jorge dan Lana Soelistianingsih (1998), 'Why Do Differences in Provincial Income Persist in Indonesia?' Bulletin of Indonesian Economic Studies 34 (1): 95-120.

Haddad, Monica. A. dan Zorica Nedović-Budić (2006), 'Using Spatial Statistics to Analyze Intraurban Inequalities and Public Intervention in São Paulo, Brazil', Journal of Human Development 7(1): 85-109.

Heikkila, Eric J. (1999), 'From HDI to hdi: A Case Study of Local Planning and Human Development in Indonesia', Regional Development Studies 5: 41-62.

Hill, Hal and Takhashi Shiraisi (2007), 'Indonesia after the Asian Crisis', Asian Economic Policy Review (2007) 2: 123-141.

Islam, lyanatul (2003), 'Dealing with spatial dimensions of inequality in Indonesia: towards a social accord', Paper for the Second Inequality and Pro-poor Growth Spring Conference on the theme of 'How Important is Horizontal Inequality'?, World Bank, Washington DC: June 9-10,2003, accessed 28/5/2008 from <http://siteresources.worldbank.org/INTDECINEQ/ Resources/DealingwithSpatialDimensions.pdf> 
Kanbur, Ravi, A. J. Venebles dan Guanghua Wan (2006), 'Spatial disparities in human development: An overview of the Asian evidence', in Kanbur Kanbur, Ravi, A. J. Venebles, Guanghua Wan (eds.), Spatial Disparities in Human Development: Perspectives from Asia, Tokyo-New York-Paris: United Nations University Press., Pp. 1-6.

Majumder, Rajarshi (2005), 'Human Development in India: Regional Pattern and Policy Issues', Indian Journal of Applied Economics 2(1).

Nordhold, Henk Schulte, and Gerry van Klinken (2007), 'Pendahuluan', in Henk Schulte Nordhold and Gerry van Klinken (eds.), Politik Lokal di Indonesia, Yayasan Obor Indonesia, Jakarta, pp. 1-41.

Resosudarmo, Budy P. dan Yogi Vidyattama (2006), 'Regional Income Disparity in Indonesia: A Panel Data Analysis', ASEAN Economic Bulletin 23(1): 31-44.

Scott, Tim (2006), 'Decentralization and Human Development: Findings and Recommendations From a Review of National Human Development Report', NHDR Occasional Paper 6. , UNDP. Suryadarma, Daniel, Wenefrida Widyanti, Asep Suryahadi, dan Sudarno Sumarto (2006), 'From Access to Income: Regional and Ethnic Inequality in Indonesia', SMERU Working Paper (May 2006).

Tadjoeddin, Mohammad Zulfan, Widjajanti I. Suharyo, dan Satish Mishra (2001), 'Regional Disparity and Vertical Conflict in Indonesia', Journal of the Asian Pacific Economy 6(3): 283304.

USAID-DRSP (2006), Stock Taking on Indonesia's Recent Decentralization Reforms-Main Report, accessed 21/5/2007 from <http://pdf.usaid.gov/pdf docs/PNADH312.pdf>. 